\title{
ADDING DIFFERENT LEVELS OF TURMERIC POWDER AND CURCUMIN IN THE DIET ON BROILER PERFORMANCE, CARCASS TRAITS, IMMUNITY AND GUT MORPHOLOGY OF BROILER CHICKEN UNDER NORMAL AND HEAT STRESS CONDITION
M. M. Mustafa ${ }^{(1)}$
F. $\operatorname{Karadas}^{(2)}$
Researcher
Prof.
Assist. Prof. \\ I. T. Tayeb ${ }^{(1)}$ \\ ${ }^{1}$ Dep. Of Animal Sci.-Coll. Agric. Engine. Sci. University of Duhok. Iraq \\ ${ }^{2}$ Yuzuncu Yil University, Faculty of Agriculture, Dep. of Animal Science. Van/ Turkey \\ E-mail: merkhan@uod.ac
}

\section{ABSTRACT}

This study was conducted to estimate the effect of adding different levels of turmeric powder and curcumin on broiler performance, carcass traits, and immunity response and jejunum histology. A total of 750 Ross day old chicks obtained from a local hatchery and distributed into two rearing conditions (normal and heat stress condition) with five treatments 3 replicate for each one had ( 25 chicks). Dietary supplements of turmeric powder and curcumin significantly $(P \leq 0.05)$ improved performance under normal and heat stress conditions. Moreover, treatments significantly $(P \leq \mathbf{0 . 0 5})$ increased the total titter antibody against Newcastle and infectious bursal disease compared to control. Concerning histology of jejunum treatments significantly $(P \leq 0.01)$ improved jejunum histology. Regarding the effect of rearing condition heat stress conditions significantly $(P \leq 0.01)$ decreased performance compared to normal rearing condition. Small intestine percent from live body weight significantly $(\mathrm{P} \leq \mathbf{0 . 0 1})$ decreased compared to normal rearing conditions. Moreover, heat stress significantly $(\mathbf{P} \leq \mathbf{0 . 0 1})$ affected the total antibody titer against Newcastle disease and infectious bursal disease. Jejunum histology significantly $(P \leq 0.01)$ affected by rearing conditions.

Key words: meat chicken, productivity, turmeric, curcumin, gut morphology, immunity

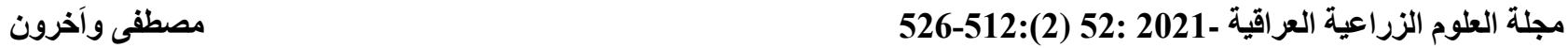

$$
\begin{aligned}
& \text { اضافة مستويات مختلفة من مسحوق الكركم الخام و الكركم المحورفي عليقة فروج اللحم على الاداء الانتاجي , صفات الذبيحة } \\
& \text {, مستوى المناعة و صحة الامعاء تحت التربيه الطبيعية و الاجهاد الحراري. } \\
& \text { احسان توفيق طيب(1) } \\
& \text { فلز كاراداش (2) }
\end{aligned}
$$

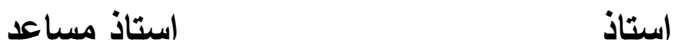

$$
\begin{aligned}
& \text { ميرخان مهذي مصطفى (1) }
\end{aligned}
$$

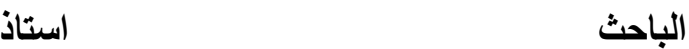

$$
\begin{aligned}
& 12 \text { قسم الاتتاج الحيواني-كلية علوم الهندسة الز ا رعية - جامعة دهوك- عراق }
\end{aligned}
$$

المستخلص

اجريت هذة التجرية في حقول كلية علوم الهنسه الزراعية/ قسم الانتاج الحيواني / جامعة دهوك لمعرفة تاثير اضافة مستويات مختلفة

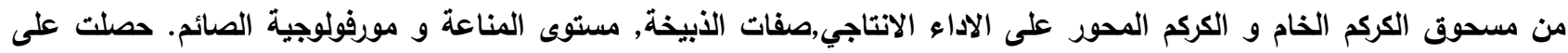

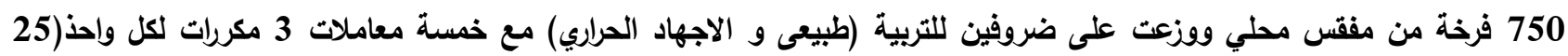

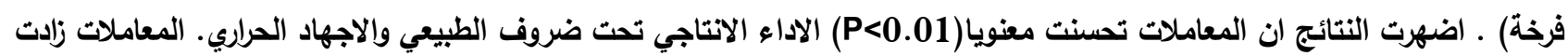
معنويا (P>0.01) مستوى المناعة ضد مرض النيوكاسل و كمبورو. المعاملات تحسنت بثكل معنوي (P>0.01 ) مواصفات الصائم.

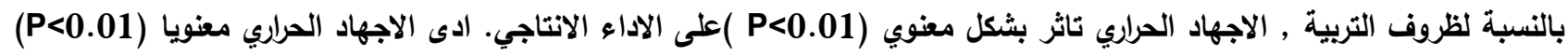

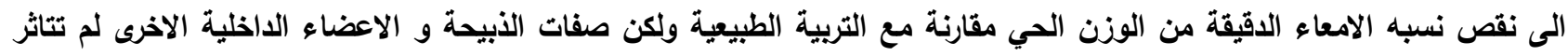

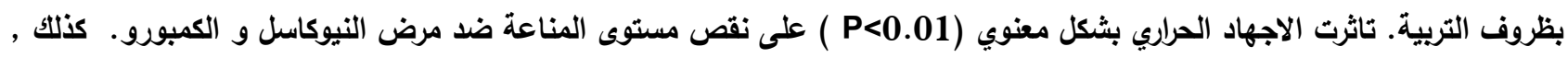

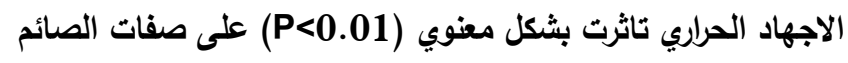

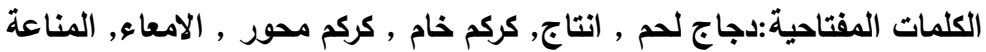




\section{INTRODUCTION}

In poultry production, high feed efficiency and rapid growth rate are the main genetic aspects considered for broiler selection. Heat stress is thought to decline the weight gain, increase feed conversion ratio, poor feed intake, increase mortality (5);(12) and immunosuppression (32) in poultry induction of oxidative stress through heat stress has been claimed as an initial factor which increases the pathogenesis of many diseases, a decline in production performance, and tends to oxidative deterioration of meat (14); (38). As a result of the expensive cooling system in the poultry house, poultry producers manipulate diet as an approach to eliminate the bad influence of high ambient temperature (19) ; (36). Some nutritional strategies which are advantageous in satisfying specific requirements and subsequently alleviating the influence of heat stress are medicinal herbs and micronutrient supplementations (22). Some of these strategies, Turmeric powder or curcumin have been used in chicken diets. This herb, which is the rhizome of Curcuma longa L. is commonly planted in southeastern and southern tropical Asia. Besides traditional medicine, this plant is widely used as coloring, spice and flavoring agents (30). The major phenolic compound of turmeric powder is curcuminoids which is an antioxidative compound that has characteristics of peroxidation inhibition, hydroxyl and superoxide anion radicals scavenge (23). Studies have stated the ability of curcumin in lipid peroxidation prevention which is considered as the main factor for many diseases progress (8). Turmeric (Curcuma longa L.) is a popular medicinal herb, which shows a wide range of pharmacological properties, such as antioxidant, antiprotozoal, anti-venom, antimicrobial, anti-inflammatory, antiproliferative, antiangiogenic, antitumor and antiaging (4). Moreover, studies found that turmeric powder promotes a positive impact on hormones and enzymes which indirectly or directly related to the broiler's health status (20). These researchers claimed that the negative effect of heat stress on some birds, which are susceptible to heat stress due to massive feed conversion ratio and production performance, might be alleviated through diet supplementation with this plant. Small intestine structure plays an important function in digestion and absorption of nutrients (21); while intestine abruption area and villus high to crypt depth ration may be altered by feed manipulation (11). Furthermore, curcumin supplementation as phenolic compounds may increase digestibility, decrease gut inflammation as well as increase metabolic activity (7). (41). Claimed that gastrointestinal tract function may be altered through these phenolic compounds Regarding the bird immunity, (9) stated that antibody titers was increased when birds fed the diet supplemented with turmeric powder or curcumin after vaccination. These might be useful to minimize the effect of such a viral disease, for example, Newcastle disease which is considered an economically important disease in the poultry industry. Enhancing the humeral immunity response and antibody titers improvement by feeding birds with a diet supplemented with herbal might be one of the satisfied strategies post-Vaccination against NDV (20);(28). Moreover, turmeric powder supplementation had similar results in increasing the titers of specific antibody against Infectious bronchitis disease (IBV) and Infectious bursal disease (IBD) (34). Therefore this study aimed to investigate the effect of adding a different level of turmeric powder and curcumin on broiler performance carcass traits, immunity response, and jejunum histology under normal and heat stress conditions.

\section{MATERIAL AND METHOD}

Birds and experimental design: Total of 750 Ross 308 day old chicks obtained from a local hatchery. On arrival, chicks were weighed (average weight of $38.67 \mathrm{~g}$ ) and were randomly distributed into two halls (275 chicks stress room, 275 chick normal condition room) with each group containing 3 replicates of 25 chicks each. The birds were reared according to the Animal Ethical Guidelines by the Department of Animal Production, College of Agricultural Engineering Sciences, University of Duhok. Chicks were kept in pens $(1.6 \mathrm{~m}$ x $2 \mathrm{~m})$. Preheating facilities were equipped for rearing room and the temperature was adjusted to 37 ${ }^{\circ} \mathrm{C}$ for the first day. Then the temperature was 
decreased gradually to $33 \pm 1$ from the third week of age until the fifth week of age. The temperature of the normal room started with $34{ }^{\circ} \mathrm{C}$ and decrease to $24{ }^{\circ} \mathrm{C}-25{ }^{\circ} \mathrm{C}$ at the $5^{\text {th }}$ week of age under continuous incandescent white light.

\section{Feed and Treatment}

The basal diet was formulated for broiler chickens according to the provisions of the National Research Council (1994) to meet the nutrients requirements of broilers (Table 1). The curcumin (Force 6® Poultry) procured from a commercial company (Phode company laboratories, France). Fresh and dried turmeric roots were obtained from local markets and the powder was made through mechanical aid. At first, powder of Curcumin or turmeric was added to a small amount of the basal diet and then a small batch of this was mixed with a larger amount of feed until the total amount of the respective diets was well mixed. The starter diet was provided to birds from 1 to 17 days, followed by a finisher diet from 18 to 35 days of age. Consumption of feed and water were free (ad libitum) to all birds. T1 was basal diet (control diet), T2 basal diet plus $50 \mathrm{~g}$ curcumin (Force $6 \AA$ Poultry) per ton, T3 basal diet plus $75 \mathrm{~g}$ curcumin (Force $6 \AA$ Poultry) per ton $\mathrm{T} 4$ basal diet plus $1.65 \mathrm{~kg}$ turmeric powder per ton of ration, T5 basal diet plus $2.5 \mathrm{~kg}$ turmeric powder per ton of ration basal diet for a period 5 weeks (35 days).

\section{Performance measurements}

The primary measurements of performance such as Feed Conversion Ratio (FCR), Feed Intake (FI), Body Weight (BW), and mortality were evaluated during 35 days of the study period. Chickens were weighed weekly and feed consumption per cage was recorded every week for each replicate in the groups. The FCR (feed intake/weight gain) was calculated as feed consumed per unit of body weight gain. Mortality was recorded per cage and has been checked daily, during the morning and evening times. Also, the average daily weight gain (DWG) and the production index were calculated for each group.

\section{Carcass measurements}

At the (35) days of age, 2 birds from each replicate were randomly selected and weighted and slaughtered manually after the starvation period for $(6-8)$ hours. Then the carcass measurements were done after feathers removal, the head, feet, and viscera then the carcass was weighted with and without edible parts (liver, gizzard, and heart). Afterward, the thigh, wing, back, breast, and neck were separated by cutting each part from the carcass and the percentage of each part was measured by dividing the weight of the part by carcass Wight of the bird. The percentage of the organs (liver, gizzard, heart, spleen, bursa, and small intestine by dividing on live body weight of the chicken were calculated

\section{Histology of the intestine (jejunum)}

At the end of the experiment, 35 days of age 2 chicken from each replicate selected randomly during carcass preparation $3 \mathrm{~cm}$ of jejunum took from the small intestine and kept in formalin solution $1 \%$. Histology parameters was measured according to (24) Gut Morphology Fixed samples were dehydrated in serial ethanol solutions, cleared in xylene, and penetrated and embedded in paraffin wax for subsequent histological analysis. Consecutive longitudinal sections $(7 \mu \mathrm{m})$ were cut with a microtome (Microm International GmbH, Walldorf, Hessen, Germany) and placed individually onto Superfrost ${ }^{\circledR}$ slides and it was stained with Hematoxylin and Eosin. Sections were examined by light microscopy (Olympus CX41microscope) using a $10 \times$ objective and color images captured with the software Analysis 5.0 (Olympus Soft) and the following parameter were measured; Parameters were villi height (from top of villi to the crypt opening, villi surface area $\left(\mu \mathrm{m}^{2}\right)$ is villi base width +villi apical width/villi apical width) $\mathrm{X}$ villi height (15), crypt depth (from the base of the crypt to the level of crypt opening) and villi height to crypt depth calculated by (dividing villus height with crypt depth. 
Table 1. the composition of the basal diets

\begin{tabular}{|c|c|c|}
\hline Ingredients (kg) & $\begin{array}{c}\text { Starter (kg/ton) } \\
1-17 \text { days }\end{array}$ & $\begin{array}{c}\text { Grower (kg/ton) } \\
18 \text { - } 35 \text { days }\end{array}$ \\
\hline Corn & 472 & 495 \\
\hline Wheat flour & 50 & 50 \\
\hline Wheat bran & 40 & 50 \\
\hline Soybean meal $46 \%$ & 370 & 340 \\
\hline Vegetable oil & 23 & 24 \\
\hline limestone & 10 & 8 \\
\hline Dicalcium phosphate & 7 & 6 \\
\hline DL methionine & 0.200 & 0.200 \\
\hline L- lysine & 1 & 0.5 \\
\hline Anti-toxin & 1 & 1 \\
\hline Salt & 1 & 1 \\
\hline Premix $^{1}$ & 25 & 25 \\
\hline Anti coccidial & 0.250 & 0.250 \\
\hline Enzyme & 0.5 & 0.5 \\
\hline \multicolumn{3}{|c|}{ Analyzed chemical composition } \\
\hline Moisture (\%) & 11.57 & 11.78 \\
\hline Crude protein (\%) & 22.49 & 20.65 \\
\hline Energy Kcal/kg & 2966 & 3055 \\
\hline Fat $(\%)$ & 2.97 & 3.36 \\
\hline Fiber $(\%)$ & 2.18 & 2.64 \\
\hline $\operatorname{Ash}(\%)$ & 4.83 & 3.34 \\
\hline $\operatorname{Starch}(\%)$ & 44.22 & 46.29 \\
\hline Sugars (\%) & 4.02 & 3.87 \\
\hline Calcium (\%) & 1.12 & 0.97 \\
\hline Available phosphorous (\%) & 0.58 & 0.53 \\
\hline
\end{tabular}

${ }^{1} 18.4 \%$ crud protein $\%, 73.4 \%$ crud ash, $0.82 \%$ crud fiber, $0.4 \%$ crude fat, $14.4 \%$ calcium, $0.21 \%$ magnesium, $6.40 \%$ sodium, $4.53 \%$ phosphorus .Additive per $\mathrm{kg}$ of premix, lysine $73.8 \mathrm{~g} / \mathrm{kg}$, methionine $82.7 \mathrm{~g} / \mathrm{kg}$, threonine $1.3 \mathrm{~g} / \mathrm{kg}$, tryptophan 0.4g/kg, Fe $2400 \mathrm{mg}$, potassium iodine80 mg, Cu $600 \mathrm{mg}$, Mn $3200 \mathrm{mg}$, Zn $2400 \mathrm{mg}$, Se 13 mg, Vit A 400000 IU, D3 12000 IU, E $2000 \mathrm{mg}$, K3 $100 \mathrm{mg}$, B1 $120 \mathrm{mg}$, B2 $300 \mathrm{mg}$, B5 $600 \mathrm{mg}$, B3 $2000 \mathrm{mg}$, B6 $200 \mathrm{mg}$, B12 $1200 \mathrm{mcg}$, B9 $60 \mathrm{mg}$, B4 $20000 \mathrm{mg}$, Vit H $6000 \mathrm{mcg}$

\section{Statistical analysis}

The SAS statistical package (PROC GLM) was used to determine the significance of the main effects (SAS, 2013). Duncan's multiple range test was used to detect the differences between individual treatment means. Statistical significance was declared at $(\mathrm{p}<0.05)$.

\section{RESULT AND DISCUSSION}

Chicken performance : The effect of adding different levels of curcumin and turmeric powder, rearing condition and their interaction on broiler performance was reported in Table 2. A significant interaction according to Duncan test has been detected between the experimental factors revealing the higher body weight and weight gain and daily weight gain in birds in $\mathrm{T} 2 \mathrm{~N}$ that were reared under normal conditions. The lower body weight and weight gain were recorded in the heat stressed birds on the control diet. In general, body weight and weight gain were improved in the additive supplemented birds compared to the control in both rearing conditions. Additive 
supplemented birds were significantly heavier and gained more weight than the control group. Birds that were reared under normal conditions had significantly higher body weight and weight gain than that of stressed birds. The results were in line with the finding of (6) who found that adding turmeric powder had a significant effect on the live body weight of broiler chicken reared under heat stress condition compared to control. And (35) found that adding a different level of curcumin has a significant effect on the live body weight of broiler chicken. Moreover (2) reported that adding turmeric powder in broiler diet reared under heat stress conditions significantly improved body weight gain. it has been found that adding curcumin in broiler diets reared under heat stress condition significantly improved live body weight compared to control diet (29). While, the result was in contrast with finding of (13) who found that adding a different level of turmeric powder had no significant effect on live body weight. Concerning of rearing condition result was in agreements with the finding of (31) who found that heat stress conditions significantly reduced broiler live body weight. The experimental factors interacted significantly according to Duncan test to increase the feed intake in birds on the $\mathrm{T} 2$ diet followed by those on the T3 diet that were reared under normal conditions. Feed intake significantly increased in T2 compared to T5. However, it was not significant when compared to the control group. Birds reared under normal conditions significantly consumed more feed than the stressed birds. There was a significant interaction between the experimental factors indicating the better FCR for birds in T2 that were reared under normal conditions. The poorer FCR was recorded for the stressed control group. The FCR was significantly improved in all additive supplemented birds compared to the control. Significantly better FCR was found in birds that were reared under normal conditions than the stressed birds.
Results were in agreement with the finding of (35) who found that adding a deferent level of curcumin had no significant effect on feed intake and significantly improved the feed conversion ratio. Moreover, (2) found that adding different levels of turmeric powder has no significant effect on feed intake of broiler under heat stress conditions. (1) Reported that adding turmeric powder to broiler diet had no significant on feed intake but improved significantly feed conversion ratio. (17) Found that adding deferent doses of turmeric extract in to broiler diets had a significant effect on FCR but feed intake didn't affected. Results were in contrast with finding of (10) who reported that adding turmeric powder in broiler diets had no significant effect on FCR. Regarding the result of the rearing, the condition was in agreement with the finding of (31) who found that heat stress conditions significantly reduced feed intake and poorer FCR compared to not stress group. The production index was significantly higher in T2 according to Duncan test under normal conditions. Furthermore, it significantly increased in all additive supplemented birds compared to the control group. The production index was higher in birds that were grown under normal conditions than the stressed birds. The experimental factors significantly interacted decreasing the mortality percentage in $\mathrm{T} 2$ that were reared under normal conditions. The mortality percentage was significantly higher in control and T4 compared to other experimental groups. The stressed birds recorded a higher mortality percentage than those that were reared under normal conditions. The result was in agreement with results previous reports that confirmed that heat stress led to increased mortality percentage significantly (2). However, there is some contrast results showed that supplementing turmeric powder in broiler diet had no significant effect on the production index (13). 
Table 2. Effect of adding different levels of turmeric powder and curcumin on broiler performance reared under normal and heat stress conditions

\begin{tabular}{|c|c|c|c|c|c|c|c|c|c|}
\hline & $\begin{array}{c}\text { Chick } \\
\text { weight } \\
\text { (g) }\end{array}$ & $\begin{array}{l}\text { Live body } \\
\text { weight (g) }\end{array}$ & Weight gain(g) & $\begin{array}{c}\text { Daily weight } \\
\text { gain (g) }\end{array}$ & Feed intake(g) & $\begin{array}{l}\text { Daily feed } \\
\text { intake (g) }\end{array}$ & $\operatorname{FCR}(\mathbf{k g} / \mathbf{k g})$ & $\begin{array}{l}\text { Production } \\
\text { index }\end{array}$ & Mortality \% \\
\hline Mean & 38.67 & $1885.10 \pm 16.8$ & $1846.42 \pm 16.88$ & $52.75 \pm 0.48$ & $2865.53 \pm 11.88$ & $81.87 \pm 0.33$ & $1.554 \pm 0.012$ & $331.07 \pm 6.62$ & $4.93 \pm 0.50$ \\
\hline T1 N & 38.92 & $1838.67 \pm 13.7 \mathrm{~d}$ & $1799.75 \pm 13.66 \mathrm{~d}$ & $51.42 \pm 0.39 \mathrm{~d}$ & $2873.63 \pm 37.08$ bcd & $82.10 \pm 1.05$ bcd & $1.596 \pm 0.008 b$ & $315.86 \pm 1.24 \mathrm{~d}$ & $4.00 \pm 0.57$ cde \\
\hline $\mathbf{T} 2 \mathrm{~N}$ & 38.61 & $2040.67 \pm 5.8 \quad a$ & $2002.05 \pm 5.64 \mathrm{a}$ & $57.20 \pm 0.16$ a & $2964.69 \pm 31.47$ a & $84.70 \pm 0.89 a$ & $1.480 \pm 0.019$ e & $388.65 \pm 7.43 \mathrm{a}$ & $1.33 \pm 0.33 \mathrm{e}$ \\
\hline T3 N & 38.72 & $1934.00 \pm 20.5 b$ & $1895.28 \pm 20.58 b$ & $54.15 \pm 0.58 b$ & $2947.25 \pm 24.28 \mathrm{ab}$ & $84.20 \pm 0.69 a b$ & $1.555 \pm 0.016$ bc & $346.00 \pm 8.91 \mathrm{bc}$ & $2.66 \pm 0.88 \mathrm{ed}$ \\
\hline T4 N & 38.90 & $1928.67 \pm 5.2 \quad b$ & $1889.75 \pm 4.98$ b & $53.99 \pm 0.14 b$ & $2855.17 \pm 24.74 \mathrm{~cd}$ & $81.57 \pm 0.70 \mathrm{~cd}$ & $1.510 \pm 0.010$ cde & $345.27 \pm 4.50$ bc & $5.33 \pm 1.33$ bcd \\
\hline T5 N & 38.58 & $1920.67 \pm 39.3 \mathrm{bc}$ & $1882.08 \pm 39.37$ bc & $53.77 \pm 1.12$ bc & $2884.27 \pm 31.20$ abc & $82.40 \pm 0.89$ abc & $1.533 \pm 0.019$ cde & $348.79 \pm 13.54$ bc & $2.66 \pm 0.66 \mathrm{ed}$ \\
\hline T1 S & 38.82 & $1697.00 \pm 8.6 \mathrm{e}$ & $1658.17 \pm 8.63 \mathrm{e}$ & $47.37 \pm 0.24 \mathrm{e}$ & $2844.49 \pm 33.57 \mathrm{~cd}$ & $81.27 \pm 0.95 \mathrm{~cd}$ & $1.715 \pm 0.020 \mathrm{a}$ & $256.24 \pm 1.67 \mathrm{e}$ & $9.33 \pm 1.33$ a \\
\hline T2 S & 38.85 & $1941.33 \pm 30.9$ b & $1902.48 \pm 30.97 \mathrm{~b}$ & $54.35 \pm 0.88 \mathrm{~b}$ & $2835.33 \pm 17.19 \mathrm{~cd}$ & $81.00 \pm 0.49 \mathrm{~cd}$ & $1.491 \pm 0.032 \mathrm{ed}$ & $357.66 \pm 13.7$ b & $4.00 \pm 0.00$ cde \\
\hline T3 S & 38.69 & $1864.67 \pm 19.6 \mathrm{~cd}$ & $1825.97 \pm 19.64 \mathrm{~cd}$ & $52.17 \pm 0.55 \mathrm{~cd}$ & $2817.47 \pm 16.42 \mathrm{~cd}$ & $80.49 \pm 0.46 \mathrm{~cd}$ & $1.543 \pm 0.007$ bcd & $326.76 \pm 4.58 \mathrm{~cd}$ & $5.33 \pm 1.33$ bcd \\
\hline T4 S & 38.50 & $1852.00 \pm 5.2 \mathrm{~d}$ & $1813.49 \pm 5.43 \mathrm{~d}$ & $51.81 \pm 0.15 \mathrm{~d}$ & $2844.04 \pm 24.01 \mathrm{~cd}$ & $81.25 \pm 0.68 \mathrm{~cd}$ & $1.568 \pm 0.017 \mathrm{bc}$ & $310.49 \pm 4.43 \mathrm{~d}$ & $8.00 \pm 0.00 \mathrm{ab}$ \\
\hline T5 S & 38.13 & $1833.33 \pm 19.8 \mathrm{~d}$ & $1795.20 \pm 19.55 \mathrm{~d}$ & $51.29 \pm 0.55 \mathrm{~d}$ & $2788.92 \pm 12.56 \mathrm{~d}$ & $79.68 \pm 0.35 \mathrm{~d}$ & $1.553 \pm 0.019$ bc & $314.98 \pm 11.64 \mathrm{~d}$ & $6.66 \pm 1.33 \mathrm{abc}$ \\
\hline Normal & 38.75 & $1932.53 \pm 18.9$ a & $1893.78 \pm 18.9$ a & $54.10 \pm 0.54$ a & $2905.00 \pm 16.18$ a & $83.00 \pm 0.46$ a & $1.535 \pm 0.012 b$ & $348.92 \pm 6.94$ a & $3.20 \pm 0.48 \mathrm{~b}$ \\
\hline Stress & 38.60 & $1837.67 \pm 22.4 \mathrm{~b}$ & $1799.06 \pm 22.4 \mathrm{~b}$ & $51.40 \pm 0.64 \mathrm{~b}$ & $2826.05 \pm 10.04 \mathrm{~b}$ & $80.74 \pm 0.28 b$ & $1.574 \pm 0.021 \mathrm{a}$ & $313.23 \pm 9.37 \mathrm{~b}$ & $6.66 \pm 0.63 \mathrm{a}$ \\
\hline T1 & 38.87 & $1767.83 \pm 32.5$ c & $1728.96 \pm 32.4 \mathrm{c}$ & $49.39 \pm 0.92 \mathrm{c}$ & $2859.06 \pm 23.30 \mathrm{ab}$ & $81.68 \pm 0.66 a b$ & $1.656 \pm 0.028 \mathrm{a}$ & $286.05 \pm 13.36 \mathrm{c}$ & $6.66 \pm 1.35$ a \\
\hline $\mathbf{T 2}$ & 38.73 & $1991.00 \pm 26.3 \mathrm{a}$ & $1952.27 \pm 26.3 \mathrm{a}$ & $55.77 \pm 0.75$ a & $2900.01 \pm 33.07$ a & $82.85 \pm 0.94$ a & $1.486 \pm 0.017 \mathrm{c}$ & $373.16 \pm 9.85$ a & $2.66 \pm 0.61 \mathrm{~b}$ \\
\hline T3 & 38.70 & $1899.33 \pm 20.0 \mathrm{~b}$ & $1860.63 \pm 19.9 \mathrm{~b}$ & $53.16 \pm 0.57 b$ & $2882.36 \pm 31.84$ ab & $82.35 \pm 0.90$ ab & $1.549 \pm 0.008 \mathrm{~b}$ & $336.38 \pm 6.21 \mathrm{~b}$ & $4.00 \pm 0.93 b$ \\
\hline T4 & 38.71 & $1890.33 \pm 17.4 \mathrm{~b}$ & $1851.62 \pm 17.3 \mathrm{~b}$ & $52.90 \pm 0.49 \mathrm{~b}$ & $2849.61 \pm 15.62 \mathrm{ab}$ & $81.41 \pm 0.44 a b$ & $1.539 \pm 0.015 b$ & $327.88 \pm 8.27 \quad b$ & $6.66 \pm 0.84 a$ \\
\hline T5 & 38.36 & $1877.36 \pm 27.7 \mathrm{~b}$ & $1838.64 \pm 27.6$ b & $52.53 \pm 0.78 \mathrm{~b}$ & $2836.59 \pm 26.09 \mathrm{~b}$ & $81.04 \pm 0.74 b$ & $1.543 \pm 0.013 b$ & $331.89 \pm 10.99 \mathrm{~b}$ & $4.66 \pm 1.11 \mathrm{ab}$ \\
\hline \multicolumn{10}{|l|}{$P$ values } \\
\hline Interaction & & 0.340 & 0.425 & 0.425 & 0.101 & 0.101 & 0.019 & 0.230 & 0.533 \\
\hline Environment & & 0.0001 & 0.0001 & 0.0001 & 0.0001 & 0.0001 & 0.003 & 0.0001 & 0.0001 \\
\hline Treatment & & 0.0001 & 0.0001 & 0.0001 & 0.155 & 0.155 & 0.0001 & 0.0001 & 0.0012 \\
\hline
\end{tabular}

T1 control, T2 50g curcumin per ton, T3 75g curcumin per ton, $\mathrm{T} 41.65 \mathrm{~kg}$ turmeric powder per ton, $\mathrm{T} 52.5 \mathrm{~kg}$ turmeric powder per ton $. \mathrm{N}=$ normal condition. $\mathrm{S}=\mathrm{heat}$ stress condition 


\section{Carcass traits}

There were non-significant effects of adding different levels of turmeric powder and curcumin on dressing percentage and carcass traits as well as the effect of rearing conditions and interaction between them were nonsignificant (Table 3). Results revealed that the highest dressing percentage was in the group fed $75 \mathrm{~g} / \mathrm{t}$ of curcumin under a normal condition however, such increase is numerical. Similarly, (18) reported that there was no significant effect of adding turmeric powder on dressing percentage, thigh, back and neck percentage compared to control. Also, (42); (40); (30) who reported that adding different level to turmeric extract in broiler diet had no significant effect on dressing percentage are parallel to our study. However, in contrast with our results, there are some reports showed that adding turmeric powder in broiler diet significantly improved dressing percentage (1) and significantly increased breast and wing percentage of broiler carcass compared to control diet (18). There was no significant effect of adding different levels of turmeric and curcumin on the internal organ as a percentage of live body weight while the rearing condition had significant $(P \leq 0.01)$ effect on small intestine percent from live body weight, while other internal parts not significantly affected by adding a different level of turmeric powder and curcumin under different rearing conditions. Small intestine percent of live body weight of chicken reared under normal was higher than those reared under heat stress conditions. (Table 3). Our results were in line with the finding of (18); (1); (40) who reported that adding a different level of turmeric powder had no significant effect on the liver, heart and spleen percent of broiler compared to control diet. Moreover, (30) who estimated that using different level of turmeric powder had no significant effect on heart, small intestine, bursa and spleen percent of live body weight compared to control. Our results were in contrast with the finding of (3) who found that adding turmeric powder in broiler diet significantly increased liver, heart, and gizzard and spleen percent compared to control diet. The results of the rearing condition was in line with the finding of (16) who found that the small intestine weight significantly decreased by heat stress compared to control. And the results were contrary to the finding of (31) who found that chicken reared under heat stress condition significantly affected the bursa and spleen relative weight percent compared to control. 
Table 3. Effect of adding different levels of turmeric powder and curcumin on dressing percentage and parts as a percent from the carcass under normal and heat stress condition

\begin{tabular}{|c|c|c|c|c|c|c|c|c|}
\hline & Dressing \% & $\begin{array}{l}\text { Dressing \% } \\
\text { with eatable } \\
\text { organs }\end{array}$ & Beast $\%$ & Thigh \% & Drum stick \% & Back \% & Wing \% & Neck \% \\
\hline Mean & $74.82 \pm 0.19$ & $79.25 \pm 0.18$ & $39.75 \pm 0.32$ & $13.94 \pm 0.20$ & $12.50 \pm 0.09$ & $18.37 \pm 0.2$ & $10.56 \pm 0.14$ & $5.34 \pm 0.07$ \\
\hline $\mathbf{T} 1 \mathrm{~N}$ & $74.36 \pm 1.04$ & $78.72 \pm 1.02$ & $39.94 \pm 1.74$ & $14.02 \pm 0.34$ & $11.91 \pm 0.44$ & $17.69 \pm 0.9$ & $10.61 \pm 0.36$ & $5.60 \pm 0.16$ \\
\hline $\mathbf{T} 2 \mathbf{N}$ & $75.39 \pm 0.44$ & $80.16 \pm 0.47$ & $37.61 \pm 1.37$ & $15.16 \pm 0.80$ & $13.06 \pm 0.30$ & $17.45 \pm 0.5$ & $11.82 \pm 0.52$ & $5.71 \pm 0.28$ \\
\hline T3 N & $76.09 \pm 0.36$ & $80.27 \pm 0.28$ & $39.96 \pm 0.66$ & $13.75 \pm 0.59$ & $12.58 \pm 0.30$ & $19.12 \pm 1.0$ & $10.42 \pm 0.21$ & $5.56 \pm 0.10$ \\
\hline T4 N & $74.43 \pm 0.51$ & $78.80 \pm 0.63$ & $40.24 \pm 0.97$ & $14.40 \pm 0.62$ & $12.39 \pm 0.31$ & $18.06 \pm 1.17$ & $10.41 \pm 0.21$ & $4.99 \pm 0.29$ \\
\hline T5 N & $74.68 \pm 0.42$ & $78.85 \pm 0.38$ & $40.78 \pm 0.91$ & $13.67 \pm 0.45$ & $12.42 \pm 0.23$ & $18.76 \pm 0.54$ & $10.66 \pm 0.32$ & $5.32 \pm 0.26$ \\
\hline T1 S & $75.28 \pm 0.83$ & $79.55 \pm 0.80$ & $40.51 \pm 0.68$ & $14.17 \pm 0.68$ & $12.14 \pm 0.29$ & $17.98 \pm 0.71$ & $10.12 \pm 0.15$ & $5.38 \pm 0.18$ \\
\hline T2 S & $73.98 \pm 0.32$ & $78.97 \pm 0.48$ & $40.20 \pm 0.71$ & $13.09 \pm 0.73$ & $12.58 \pm 0.38$ & $19.08 \pm 0.67$ & $9.78 \pm 0.26$ & $5.33 \pm 0.22$ \\
\hline T3 S & $74.27 \pm 0.57$ & $78.92 \pm 0.33$ & $39.46 \pm 1.03$ & $13.66 \pm 0.67$ & $12.40 \pm 0.14$ & $19.42 \pm 0.89$ & $10.48 \pm 0.36$ & $4.76 \pm 0.22$ \\
\hline T4 S & $74.90 \pm 0.65$ & $79.17 \pm 0.64$ & $39.70 \pm 0.73$ & $13.56 \pm 0.62$ & $12.79 \pm 0.33$ & $18.18 \pm 0.65$ & $11.08 \pm 1.07$ & $5.39 \pm .28$ \\
\hline T5 S & $74.80 \pm 0.49$ & $79.04 \pm 0.50$ & $39.10 \pm 0.97$ & $13.90 \pm 1.09$ & $12.70 \pm 0.27$ & $17.92 \pm 1.10$ & $10.28 \pm 0.18$ & $5.40 \pm 0.32$ \\
\hline Normal & $74.99 \pm 0.28$ & $79.36 \pm 0.28$ & $39.70 \pm 0.53$ & $14.20 \pm 0.26$ & $12.47 \pm 0.15$ & $18.22 \pm 0.39$ & $10.78 \pm 0.17$ & $5.44 \pm 0.10$ \\
\hline Stress & $74.64 \pm 0.26$ & $79.13 \pm 0.24$ & $39.79 \pm 0.36$ & $13.68 \pm 0.30$ & $12.52 \pm 0.12$ & $18.52 \pm 0.36$ & $10.35 \pm 0.23$ & $5.25 \pm 0.11$ \\
\hline T1 & $74.82 \pm 0.65$ & $79.13 \pm 0.63$ & $40.22 \pm 0.89$ & $14.09 \pm 0.18$ & $12.02 \pm 0.25$ & $17.84 \pm 0.57$ & $10.36 \pm 0.20$ & $5.49 \pm 0.12$ \\
\hline $\mathbf{T 2}$ & $74.68 \pm 0.33$ & $79.57 \pm 0.37$ & $38.90 \pm 0.83$ & $14.12 \pm 0.60$ & $12.82 \pm 0.24$ & $18.26 \pm 0.48$ & $10.80 \pm 0.41$ & $5.52 \pm 0.18$ \\
\hline T3 & $75.18 \pm 0.42$ & $79.59 \pm 0.29$ & $39.71 \pm 0.59$ & $13.71 \pm 0.43$ & $12.49 \pm 0.16$ & $19.27 \pm 0.67$ & $10.45 \pm 0.20$ & $5.16 \pm 0.16$ \\
\hline T4 & $74.67 \pm 0.40$ & $78.99 \pm 0.43$ & $39.97 \pm 0.58$ & $13.98 \pm 0.43$ & $12.59 \pm 0.22$ & $18.12 \pm 0.64$ & $10.75 \pm 0.53$ & $5.19 \pm 0.20$ \\
\hline T5 & $74.74 \pm 0.31$ & $78.95 \pm 0.30$ & $39.94 \pm 0.68$ & $13.79 \pm 0.56$ & $12.56 \pm 0.17$ & $18.34 \pm 0.60$ & $10.47 \pm 0.18$ & $5.36 \pm 0.19$ \\
\hline \multicolumn{9}{|l|}{$P$ values } \\
\hline Interaction & 0.112 & 0.270 & 0.317 & 0.388 & 0.603 & 0.728 & 0.0544 & 0.157 \\
\hline Environment & 0.375 & 0.549 & 0.892 & 0.216 & 0.796 & 0.568 & 0.131 & 0.245 \\
\hline Treatment & 0.911 & 0.701 & 0.750 & 0.958 & 0.150 & 0.544 & 0.827 & 0.458 \\
\hline
\end{tabular}

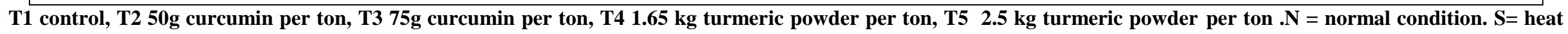
stress condition 
Table 4. Effect of adding different levels of turmeric powder and curcumin in broiler diet on organ percent from the live body weight of chicken reared under normal and heat stress condition

\begin{tabular}{|c|c|c|c|c|c|c|}
\hline & Liver \% & Heart \% & Gizzard \% & Spleen \% & Bursa \% & $\begin{array}{l}\text { Small intestine } \\
\%\end{array}$ \\
\hline Mean & $2.42 \pm 0.04$ & $0.48 \pm 0.8$ & $1.46 \pm 0.02$ & $0.13 \pm 0.005$ & $0.15 \pm 0.005$ & $2.96 \pm 0.09$ \\
\hline T1 N & $2.36 \pm 0.14$ & $0.50 \pm 0.1$ & $1.49 \pm 0.07$ & $0.11 \pm 0.013$ & $0.14 \pm 0.012$ & $3.17 \pm 0.41$ \\
\hline T2 N & $2.84 \pm 0.08$ & $0.51 \pm 0.02$ & $1.40 \pm 0.10$ & $0.12 \pm 0.022$ & $0.14 \pm 0.020$ & $3.51 \pm 0.19$ \\
\hline T3 N & $2.27 \pm 0.10$ & $0.50 \pm 0.02$ & $1.39 \pm 0.02$ & $0.09 \pm 0.018$ & $0.18 \pm 0.018$ & $3.34 \pm 0.21$ \\
\hline T4 N & $2.39 \pm 0.15$ & $0.51 \pm 0.03$ & $1.47 \pm 0.07$ & $0.13 \pm 0.030$ & $0.16 \pm 0.012$ & $3.08 \pm 0.31$ \\
\hline T5 N & $2.18 \pm 0.08$ & $0.46 \pm 0.02$ & $1.51 \pm 0.10$ & $0.11 \pm 0.011$ & $0.18 \pm 0.016$ & $2.89 \pm 0.13$ \\
\hline T1 S & $2.28 \pm 0.10$ & $0.46 \pm 0.02$ & $1.56 \pm 0.09$ & $0.12 \pm 0.022$ & $0.15 \pm 0.028$ & $2.59 \pm 0.27$ \\
\hline T2S & $2.35 \pm 0.19$ & $0.44 \pm 0.04$ & $1.53 \pm 0.05$ & $0.14 \pm 0.019$ & $0.10 \pm 0.016$ & $2.28 \pm 0.48$ \\
\hline T3 S & $2.68 \pm 0.24$ & $0.49 \pm 0.02$ & $1.46 \pm 0.05$ & $0.15 \pm 0.016$ & $0.15 \pm 0.016$ & $3.09 \pm 0.15$ \\
\hline T4 S & $2.43 \pm 0.16$ & $0.46 \pm 0.02$ & $1.36 \pm 0.08$ & $0.11 \pm 0.020$ & $0.15 \pm 0.010$ & $2.66 \pm 0.16$ \\
\hline T5 S & $2.39 \pm 0.08$ & $0.45 \pm 0.01$ & $1.39 \pm 0.07$ & $0.18 \pm 0.029$ & $0.14 \pm 0.023$ & $2.95 \pm 0.10$ \\
\hline Normal & $2.41 \pm 0.06$ & $0.50 \pm 0.01$ & $1.45 \pm 0.03$ & $0.11 \pm 0.008$ & $0.16 \pm 0.007$ & $3.20 \pm 0.11 \quad a$ \\
\hline Stress & $2.43 \pm 0.07$ & $0.46 \pm 0.01$ & $1.46 \pm 0.03$ & $0.14 \pm 0.011$ & $0.14 \pm 0.008$ & $2.72 \pm 0.12 \quad b$ \\
\hline T1 & $2.32 \pm 0.08$ & $0.48 \pm 0.01$ & $1.53 \pm 0.06$ & $0.11 \pm 0.012$ & $0.14 \pm 0.014$ & $2.88 \pm 0.25$ \\
\hline $\mathbf{T} 2$ & $2.60 \pm 0.12$ & $0.48 \pm 0.02$ & $1.47 \pm 0.06$ & $0.13 \pm 0.014$ & $0.12 \pm 0.014$ & $2.90 \pm 0.30$ \\
\hline T3 & $2.48 \pm 0.14$ & $0.50 \pm 0.01$ & $1.42 \pm 0.02$ & $0.12 \pm 0.016$ & $0.17 \pm 0.012$ & $3.22 \pm 0.13$ \\
\hline T4 & $2.41 \pm 0.10$ & $0.49 \pm 0.02$ & $1.42 \pm 0.05$ & $0.12 \pm 0.017$ & $0.16 \pm 0.008$ & $2.87 \pm 0.18$ \\
\hline T5 & $2.92 \pm 0.08$ & $0.45 \pm 0.01$ & $1.45 \pm 0.06$ & $0.15 \pm 0.018$ & $0.16 \pm 0.014$ & $2.92 \pm 0.08$ \\
\hline \multicolumn{7}{|l|}{$P$ values } \\
\hline Interaction & 0.0416 & 0.678 & 0.389 & 0.224 & 0.759 & 0.202 \\
\hline Environments & 0.842 & 0.0528 & 0.870 & 0.075 & 0.063 & 0.007 \\
\hline Treatment & 0.226 & 0.635 & 0.640 & 0.590 & 0.148 & 0.684 \\
\hline
\end{tabular}

T1 control, T2 50g curcumin per ton, T3 75g curcumin per ton, T4 $1.65 \mathrm{~kg}$ turmeric powder per ton, $\mathrm{T} 52.5 \mathrm{~kg}$ turmeric powder per ton $. \mathrm{N}=$ normal condition. $\mathrm{S}=$ heat stress condition

Immunity response

The total antibodies titers of Newcastle and infectious bursal disease results were shown in Table (5). Both were lower in the T1 S group (3831.67 and 5482.83, respectively) compared with other groups. While, there was also an increase $(\mathrm{P}<0.01)$ in total titers of Newcastle and infectious bursal disease according to Duncan test in the T2N (6405.83 and 7133.67, respectively) and T5N (6319.83 and 7087.17, respectively) groups compared to the other groups. The additives used in this study under different levels of rearing conditions did not showed any significant effect on the total antibody against Infectious bronchitis response at 35 days of age (Table 5). The addition of curcumin and turmeric powder had a significant $(\mathrm{P}<0.01)$ effect on total antibodies titers of Newcastle and infectious bursal disease. Total antibodies titers of Newcastle disease were higher $(\mathrm{P}<0.01)$ in the $\mathrm{T} 2$ and $\mathrm{T} 5$ groups compared with the control group. Regarding infectious bursal disease, the T2, $\mathrm{T} 3$, and $\mathrm{T} 5$ groups recorded higher $(\mathrm{P}<0.01)$ total antibodies titers compared to the control group (Table 5). While, there was no significant effect of additives on the titer of infectious bronchitis the results were in agreements with the finding of (34) who reported that adding different levels of turmeric powder had no significant effect on the antibody titer against infectious bronchitis. Moreover, (25) showed that adding 1\% turmeric powder in broiler diet significantly increased the total antibody titer against Newcastle disease. On the other hand, results were contrary to the finding of (34) who found that adding turmeric powder in broiler diet had no significant effect on anti-body titter against Newcastle and infectious bursal disease. Also, 
(37) found that adding addition turmeric to broiler drinking water had no significant effect on total antibody titer against Newcastle disease. Rearing conditions had a significant effect on total antibodies titers of Newcastle and infectious bursal disease. While infectious bronchitis was not significantly affected. Chickens reared under stress conditions lead to reduce $(\mathrm{P}<0.01)$ the total antibodies titers

Table 5. Effect of adding different levels of turmeric powder and curcumin in broiler diet on total antibody titter against infectious bronchitis, Newcastle disease and infectious bursal disease of chicken reared under normal and heat stress condition

\begin{tabular}{|c|c|c|c|}
\hline & Infectious bronchitis & Newcastle disease & Infectious bursal disease \\
\hline Mean & $3638.35 \pm 49.41$ & $5240.48 \pm 107.98$ & $6292.28 \pm 108.40$ \\
\hline T1 N & $3604.67 \pm 88.66$ & $4805.17 \pm 224.25$ b & $6130.50 \pm 311.40 \mathrm{~d}$ \\
\hline T2 N & $3620.83 \pm 217.09$ & $6405.83 \pm 197.44$ a & $7133.67 \pm 80.38 \quad$ a \\
\hline T3 N & $3626.33 \pm 175.51$ & $5260.83 \pm 74.43 \quad$ b & $6990.17 \pm 134.10$ abc \\
\hline T4 N & $3663.00 \pm 46.62$ & $5159.67 \pm 109.82$ b & $6124.17 \pm 238.63 \mathrm{~cd}$ \\
\hline T5 N & $3654.33 \pm 189.60$ & $6319.83 \pm 261.90 a$ & $7087.17 \pm 208.81$ ab \\
\hline T1 S & $3621.17 \pm 82.91$ & $3831.67 \pm 148.15 \mathrm{c}$ & $5482.83 \pm 389.13 \mathrm{~d}$ \\
\hline T2 S & $3639.17 \pm 173.11$ & $5344.50 \pm 208.45 \quad b$ & $6291.17 \pm 279.09$ bcd \\
\hline T3 S & $3665.17 \pm 253.75$ & $5134.17 \pm 279.84 \quad b$ & $5953.83 \pm 359.04 d$ \\
\hline T4 S & $3627.83 \pm 184.79$ & $4976.00 \pm 274.19 \mathrm{~b}$ & $5525.50 \pm 274.76 \mathrm{~d}$ \\
\hline T5 S & $3661.00 \pm 167.34$ & $5167.17 \pm 146.15$ b & $6113.83 \pm 285.09 d$ \\
\hline Normal & $3633.83 \pm 65.49$ & $5590.27 \pm 143.48$ a & $6711.13 \pm 120.10$ \\
\hline Stress & $3642.87 \pm 75.13$ & $4890.70 \pm 135.74 \quad b$ & $5873.43 \pm 145.91 \quad b$ \\
\hline $\mathbf{T 1}$ & $3612.92 \pm 57.92$ & $4318.42 \pm 194.82$ c & $5806.67 \pm 256.87 \quad b$ \\
\hline $\mathbf{T 2}$ & $3630.00 \pm 132.40$ & $5875.17 \pm 210.56$ a & $6172.42 \pm 187.89$ \\
\hline $\mathbf{T 3}$ & $3645.42 \pm 147.20$ & $5197.50 \pm 139.36 \quad b$ & $6472.00 \pm 240.40 \mathrm{a}$ \\
\hline $\mathbf{T 4}$ & $3645.67 \pm 91.01$ & $5067.83 \pm 143.51 \quad$ b & $5869.83 \pm 202.18 \quad b$ \\
\hline T5 & $3657.67 \pm 120.56$ & $5743.50 \pm 225.03 \quad$ a & $6600.50 \pm 223.41$ a \\
\hline \multicolumn{4}{|l|}{$P$ value } \\
\hline Interaction & 0.999 & 0.026 & 0.938 \\
\hline Environment & 0.933 & 0.0001 & 0.0001 \\
\hline Treatments & 0.999 & 0.0001 & 0.0021 \\
\hline
\end{tabular}

T1 control, T2 50g curcumin per ton, T3 $75 \mathrm{~g}$ curcumin per ton, T4 $1.65 \mathrm{~kg}$ turmeric powder per ton, $\mathrm{T} 52.5 \mathrm{~kg}$ turmeric powder per ton $. N=$ normal condition. $S=$ heat stress condition

Different litter at the same column are significantly differ

Jejunum traits

Overall, feeding chicken under rearing conditions had significant effects on most of the studied traits. T2N had significantly increased villus height, villi apical width, villi base width, surface area, and villi height/ crypt against both Newcastle and infectious bursal disease. These results were in line with the finding of (27) who showed that chicken reared under heat stress significantly have lower antibody titer against Newcastle disease compared to normal condition. Moreover, (31) reported that stress condition significantly decreased the body titter compared to control. 
contrast, feeding chicken under stress condition had significantly decreased most of the traits.T1S significantly decreased villus height, villi apical width, surface area, and villi height /crypt depth being 864.29, 74.32, 2029.54, and 2.13, respectively. Additionally, the rest of the traits; muscle thickness and villi base width were significantly decreased in T4N being 85.77 and 85.45 , respectively. Finally, crypt depth was significantly increased in T1S being 409.88 (Table 6). Additionally, different levels of turmeric powder and curcumin in the broiler diet had significant effects on jejunum histology (Table 6 ). Most of the best significant results were obtained in T2 compared to control. While muscle thickness was significantly higher in $\mathrm{T} 3$ and T5 compared to the control group. The results were in agreement with the finding of (33) who found that adding a different level of turmeric powder significantly increased villi height $(\mu \mathrm{m})$, villi surface area $\left(\mu \mathrm{m}^{2}\right)$, villi height to crypt depth and decreased crypt depth $(\mu \mathrm{m})$. Also, (35) showed that dietary supplementation of curcumin was significanlty influenced the histomorphological measurements of small intestine villus height $(\mu \mathrm{m})$, villus width $(\mu \mathrm{m})$ and crypt depth $(\mu \mathrm{m})$ compared to the control diet. In contrast with our finding (35) investigated that adding a different level of curcumin in broiler diet had no significant effect on the villi height to crypt depth Considering the rearing conditions, chicken which was raised in heat stress condition had significantly lower villus height, villi apical width, villi base width, surface area and villi height/crypt depth being 1089.51, 94.68, 105.65, 2312.88 and 3.69. Additionally, stress rearing condition significantly increased crypt depth (315.60). However, muscle thickness was significantly lower in normal rearing conditions (214). These obtained results were in line with the finding of (39) who indicated that chicken reared under stress condition significantly affected on the villi height $(\mu \mathrm{m})$, villi width $(\mu \mathrm{m})$, crypt depth $(\mu \mathrm{m})$ and surface area $\left(\mu \mathrm{m}^{2}\right)$ of jejunum compared to normal thermal condition. Our results was in contrast with the finding of (16) who found that stress conditions had no significant effect on the jejunum villi height $(\mu \mathrm{m})$, villi width $(\mu \mathrm{m})$ and villi height to crypt depth compared to normal thermal condition. Also, (39) estimated that heat stress conditions had no significant effect on the villi height to crypt depth ratio of jejunum compared to normal conditions. Furthermore, (26) mentioned that heat stress had no significant effect on the jejunum villi height, and crypt depth of broiler compared to control. 
Table 6. Effect of adding different levels of turmeric powder and curcumin in broiler diet on of jejunum histology of chicken reared under normal and heat stress condition

\begin{tabular}{|c|c|c|c|c|c|c|c|}
\hline & Villus height $\mu \mathrm{m}$ & Crypt depth $\mu \mathrm{m}$ & $\begin{array}{c}\text { Muscle thickness } \\
\mu \mathrm{m}\end{array}$ & $\begin{array}{l}\text { Villi apical } \\
\text { width } \mu \mathrm{m}\end{array}$ & $\begin{array}{c}\text { Villi base width } \\
\mu \mathrm{m}\end{array}$ & $\begin{array}{l}\text { Surface area } \\
{\mu \mathrm{m}^{2}}^{2^{2}}\end{array}$ & $\begin{array}{l}\text { Villi height / } \\
\text { crypt depth }\end{array}$ \\
\hline Mean & $1172.04 \pm 7.17$ & $274.06 \pm 2.86$ & $217.60 \pm 1.63$ & $97.42 \pm 0.81$ & $107.24 \pm 0.70$ & $2468.35 \pm 12.65$ & $4.63 \pm 0.06$ \\
\hline T1 N & $1077.19 \pm 4.40 \mathrm{~g}$ & $271.40 \pm 3.52 \mathrm{~d}$ & $187.54 \pm 3.68 \mathrm{~d}$ & $81.70 \pm 1.29 \mathrm{~g}$ & $103.01 \pm 1.82 \mathrm{e}$ & $2449.90 \pm 30.45 \mathrm{e}$ & $4.01 \pm 0.05 g$ \\
\hline T2 N & $1443.69 \pm 1.86 a$ & $200.03 \pm 1.05 \mathrm{~g}$ & $223.41 \pm 5.91 b$ & $127.42 \pm 0.58 \mathrm{a}$ & $132.92 \pm 0.85 a$ & $2949.86 \pm 3.81 \mathrm{a}$ & $7.22 \pm 0.39 a$ \\
\hline T3 N & $1263.89 \pm 3.02 \mathrm{~d}$ & $201.28 \pm 0.99 \mathrm{~g}$ & $257.49 \pm 4.81 \mathrm{a}$ & $113.75 \pm 0.63 c$ & $119.25 \pm 0.63 c$ & $2588.99 \pm 6.11 \mathrm{~d}$ & $6.28 \pm 0.03 b$ \\
\hline T4 N & $1111.41 \pm 5.48 \mathrm{f}$ & $262.45 \pm 3.39$ & $185.77 \pm 2.23 d$ & $79.95 \pm 0.36 \mathrm{~g}$ & $85.45 \pm 0.36 h$ & $2299.36 \pm 11.36 \mathrm{~g}$ & $4.28 \pm 0.06 \mathrm{e}$ \\
\hline T5 N & $1376.67 \pm 3.02 b$ & $225.88 \pm 1.36 \mathrm{f}$ & $215.81 \pm 2.95 b c$ & $98.00 \pm 0.84 \mathrm{e}$ & $103.50 \pm 0.84 \mathrm{e}$ & $2830.95 \pm 6.31 b$ & $6.10 \pm 0.04 c$ \\
\hline T1 S & $864.29 \pm 5.01$ & $409.88 \pm 5.33$ a & $195.83 \pm 2.62 d$ & $74.32 \pm 1.46 h$ & $98.35 \pm 1.90 \mathrm{f}$ & $2029.54 \pm 31.28 \mathrm{i}$ & $2.13 \pm 0.03 i$ \\
\hline T2S & $1302.76 \pm 7.29 \mathrm{c}$ & $229.84 \pm 1.65$ f & $208.42 \pm 3.37 c$ & $122.37 \pm 0.86 b$ & $128.64 \pm 0.84 b$ & $2672.57 \pm 14.60 c$ & $5.47 \pm 0.05 d$ \\
\hline T3 S & $1162.89 \pm 3.02$ & $289.07 \pm 4.72 \mathrm{c}$ & $220.70 \pm 4.46 \mathrm{bc}$ & $108.75 \pm 0.63 d$ & $114.31 \pm 0.62 d$ & $2385.45 \pm 6.13 \mathrm{f}$ & $4.10 \pm 0.08 \mathrm{fg}$ \\
\hline T4S & $957.39 \pm 7.31 \quad h$ & $372.05 \pm 3.12 \quad b$ & $220.17 \pm 3.72$ bc & $74.95 \pm 0.36 h$ & $88.45 \pm 0.36 \mathrm{~g}$ & $2087.47 \pm 15.97$ h & $2.58 \pm 0.03 h$ \\
\hline T5 S & $1160.19 \pm 4.05 \mathrm{e}$ & $278.68 \pm 1.62 d$ & $260.83 \pm 5.61 \mathrm{a}$ & $93.00 \pm 0.84 f$ & $98.50 \pm 0.84 \mathrm{f}$ & $2389.36 \pm 8.45$ f & $4.17 \pm 0.03$ ef \\
\hline Normal & $1254.57 \pm 8.45 a$ & $232.21 \pm 2.02 \quad b$ & $214.00 \pm 2.38 b$ & $100.83 \pm 1.12 \mathrm{a}$ & $108.83 \pm 10.3 \mathrm{a}$ & $2623.81 \pm 15.38 \mathrm{a}$ & $5.58 \pm 0.07 a$ \\
\hline Stress & $1089.51 \pm 9.44 b$ & $315.60 \pm 4.12 a$ & $221.19 \pm 2.21 \mathrm{a}$ & $94.68 \pm 1.16 \quad b$ & $105.65 \pm 0.94 b$ & $2312.88 \pm 15.59 b$ & $3.69 \pm 0.07 b$ \\
\hline T1 & $970.74 \pm 10.30$ & $340.64 \pm 7.10$ a & $191.69 \pm 2.28 d$ & $78.01 \pm 1.03 \mathrm{~d}$ & $100.68 \pm 1.32 \mathrm{c}$ & $2239.72 \pm 29.04 d$ & $3.07 \pm 0.09 d$ \\
\hline $\mathbf{T} 2$ & $1373.23 \pm 7.46 \quad a$ & $214.94 \pm 1.67$ e & $215.91 \pm 3.45 \mathrm{~b}$ & $124.89 \pm 0.64 a$ & $130.78 \pm 0.62 a$ & $2811.21 \pm 14.76 \mathrm{a}$ & $6.35 \pm 0.08 a$ \\
\hline T3 & $1213.39 \pm 5.09 c$ & $245.17 \pm 4.68 d$ & $239.10 \pm 3.67 a$ & $111.78 \pm 0.50 b$ & $116.78 \pm 0.50 b$ & $2487.22 \pm 10.27 c$ & $5.19 \pm 0.10 b$ \\
\hline $\mathbf{T 4}$ & $1034.43 \pm 10.23 \mathrm{~d}$ & $317.25 \pm 5.52 \quad b$ & $202.97 \pm 2.67 \mathrm{c}$ & $77.45 \pm 0.34 \mathrm{~d}$ & $86.95 \pm 0.29 d$ & $2193.41 \pm 13.76 \mathrm{e}$ & $3.43 \pm 0.08 \mathrm{c}$ \\
\hline T5 & $1268.43 \pm 10.23 b$ & $252.28 \pm 2.64 \mathrm{c}$ & $238.32 \pm 3.77 a$ & $95.50 \pm 0.63 \mathrm{c}$ & $101.00 \pm 0.63 \mathrm{c}$ & $2610.16 \pm 20.91 b$ & $5.14 \pm 0.09 \mathrm{e}$ \\
\hline$P$ value & & & & & & & \\
\hline Interaction & 0.0001 & 0.0001 & 0.0001 & 0.578 & 0.0002 & 0.0001 & 0.0001 \\
\hline Environment & 0.0001 & 0.0001 & 0.005 & 0.0001 & 0.0001 & 0.0001 & 0.0001 \\
\hline Treatments & 0.0001 & 0.0001 & 0.0001 & 0.0001 & 0.0001 & 0.0001 & 0.0001 \\
\hline
\end{tabular}

T1 control, T2 50g curcumin per ton, $T 375 \mathrm{~g}$ curcumin per ton, $\mathrm{T} 41.65 \mathrm{~kg}$ turmeric powder per ton, $\mathrm{T} 52.5 \mathrm{~kg}$ turmeric powder per ton $. \mathrm{N}=$ normal condition. $\mathrm{S}=\mathrm{heat}$ stress condition 


\section{CONCLUSION}

In conclusion supplement of $50-75 \mathrm{~g}$ of curcumin per ton and $1.65-2.5 \mathrm{~kg} /$ ton turmeric powder improved live body weight, weight gain, feed intake, feed conversion ratio, production index, morality, immunity response and histology of jejunum compared to control under both normal and heat stress conditions. While do not significantly affect the carcass traits and internal organs under both rearing conditions.

\section{REFERENCES}

1-Abo El-Maaty, M.A., M.H. Rabie and A.Y. El-Khateeb. 2014. Response of heat-stressed broiler chicks to dietary supplementation with some commercial herbs. Asian J Anim Vet Adv. 9 (12):743-55.

2-Akhavan-Salamat H. \& H. A Ghasemi. 2015. Alleviation of chronic heat stress in broilers by dietary supplementation of betaine and turmeric rhizome powder: dynamics of performance, leukocyte profile, humoral immunity and antioxidant status. Trop Anim Health Prod. 48(1) 181-188.

3-Alagawany, M.M., R.F. Mayada and K. Dhama. 2015. Nutritional and biological effect of turmeric (curcuma longa supplementation on performance, serum biochemical parameters and oxidative status of broiler chicks exposed to endosulfan in the diet. Asian journal of animal and veterinary advances. 10 (2):86 -96.

4-Amalraj, A., A. Pius, S. Gopi and S. Gopi. 2017. Biological activities of curcuminoids, other biomolecules from turmeric and their derivatives - a review. J. Tradit. Complement. Med. 7 (2):205-233.

5-Attia, Y.A., R.A. Hassan and E.M.A. Qota. 2009. Recovery from adverse effects of heat stress on slow-growing chicks in the tropics 1 : Effect of ascorbic acid and different levels of betaine. Tropical Animal Health and Production. 41 (5):807-818.

6-Baghban P., M. Daneshyar \& R. Najafi. 2016. Effects of Cinnamon (Cinnamomum zeylanicum) and Turmeric (Curcuma longa) Powders on Performance, Enzyme Activity, and Blood Parameters of Broiler Chickens under Heat Stress. Poultry Science Journal, 4 (1): 47-53.

7-Buchanan, N.P., J.M. Hott, S.E. Cutlip, A.L. Rack, A.A. Asamer and J.S. Moritz. 2008. The effects of a natural antibiotic alternative and a natural growth promoter feed additive on broiler performance and carcass quality. Journal Applied Poultry Research. 17 (2):202210.

8-Daneshyar, M., H. Kermanshahi and A. Golian. 2012. The effects of turmeric supplementation on antioxidant status, blood gas indices and mortality in broiler chickens with T3-induced ascites. British Poultry Science. 53 (3):379-385.

9-Faghani, M., A. Rafiee, A.R. Namjoo, and Y. Rahimian. 2014. Performance, cholesterol profile and intestinal microbial population in broilers fed turmeric extract. Res. Opin. Anim. Vet. Sci. 4 (9):500-503.

10-Fallah, R., and E. Mirzaei. .2016. Effect of dietary inclusion of turmeric and thyme powders on performance, blood parameters and immune system of broiler chickens. Livest. Sci. 7 (1):180-186.

11-Fasina, Y.O., H.L. Classen, J.D. Garlich, B.L. Black, P.R. Ferket, Z. Uni and A.A. Olkowski. 2006. Response of turkey poults to soybean lectin levels typically encountered in commercial diets. 2. Effect on intestinal development and lymphoid organs. Poultry Science. 85 (5):870-877.

12-Günal, M. 2013. The effects of early-age thermal manipulation and daily short-term fasting on performance and body temperatures in broiler exposed to heat stress. Journal of Animal Physiology and Animal Nutrition. 97 (5):854-860.

13-Hosseini-Vashan, S.J., A. Golian, A. Yaghobfar, A. Zarban, N. Afzali and P. Esmaeilinasab. 2012. Antioxidant status, immune system, blood metabolites and carcass characteristic of broiler chickens fed turmeric rhizome powder under heat stress. African Journal of Biotechnology. 11 (94):16118-25. 14-Huang, C., H. Jiao, Z. Song, J. Zhao, X. Wang and H. Lin. 2015. Heat stress impairs mitochondria functions and induces oxidative injury in broiler chickens. Journal of Animal Science. 93 (5):2144-2153.

15-Iji, P.A., R.J. Hughes, M. Choct and D.R. Tivey. 2001. Intestinal structure and function of broiler chickens on wheat-based diets supplemented with a microbial enzyme. AsianAustralasian Journal of Animal Sciences. 14 (1):54-60. 
16-Jahejo A. R., I. H. Leghari, A. Sethar, M. N. Rao, M. Nisa, G. H. Sethar. 2016. Effect of heat stress and ascorbic acid on gut morphology of broiler chicken. Sindh Univ. Res. Jour. (Sci. Ser.) Vol. 48 (4) 829-832.

17-Johannah, N.M., A. Joseph, B. Maliakel and I.M. Krishnakumar. 2018. Dietary addition of a standardized extract of turmeric (TurmaFEED TM) improves growth performance and carcass quality of broilers. Journal of animal science and technology. 60 (1):8.

18-Kafi, A., M.N. Uddin, M.J. Uddin, M.M.H. Khan and M.E. Haque. 2017. Effect of Dietary Supplementation of Turmeric (Curcuma longa), Ginger (Zingiber officinale) and their Combination as Feed Additives on Feed Intake, Growth Performance and Economics of Broiler. Int. J.poult.Sci. 16 (7):257-265.

19-Khan, R.U., S. Naz, , Z. Nikousefat, , M. Selvaggi, V. Laudadio and V. Tufarelli. 2012. Effect of ascorbic acid in heat-stressed poultry. World's Poultry Science Journal. 68 (3):477490.

20-Kumari, P., M.K. Gupta, R. Ranjan, K.K. Singh and R. Yadava. 2007. Curcuma longa as feed additive in broiler bird and its pathophysiological effects. Indian J. Exp. Biol. 45: 272-277.

21-Lenhardt, L. and S. Mozes. 2003. Morphological and functional changes of the small intestine in growth-stunted broilers. Acta Veterinaria. 72 (3):353-358.

22-Lin, H., H.C. Jiao, J. Buyse and E. Decuypere. 2006. Strategies for preventing heat stress in poultry. Worlds Poult. Sci J. 62 (1):71-86.

23-Ling, J., B. Wei, G. Lv, H. Ji and S. Li. 2012. Anti-hyperlipidaemic and antioxidant effects of turmeric oil in hyperlipidaemic rats. Food Chemistry. 130 (2):229-235.

24-M' Sadeq S.A.2019. Effect of dietary supplementation of miaclost on performance and gut morphology in broiler chickens challenged with E.coli. Iraqi journal of agricultural science 2 (50) 506-514.

25-Madbouly, H.M., M.A. Saif and A.S. Hussein. 2011. Curcuma longa for protecting chicks against Newcastle disease virus infection and immunosuppressive effect of Marek's disease viral vaccine.int. J. Virol. 7 (4):176-183.
26-Marchini, C.F.P, P.L. Silva, M.R.B.M. Nascimento , M.E. Bletti, N.M. Silva and E.C.Guimaraes. 2011. Body weight, intestinal morphology and cell proliferation of broiler chickens submitted to cyclic heat stress. International journal of poultry science. 10 (6):455-460.

27-Maurina L. P, P. E. N. Givisiez , E.P. Saraiva, F G. P. Costa, E. G. Dos santos and A.L.B.M. Filho .2012. Threonine and chronic heat stress affect Newcastle antibody titers of broilers in the pre-initial and initial phases. WPC2012 - Salvador - Bahia - Brazil • 5 - 9. 28-Moomivand, H., M.R. Bassami, S. Faramarzi, E. Stabraghi, A. Ghaedi, H. Ghabel, A. Zarghami and M. Banaei. 2013. Serological and clinical survey of Newcastle disease in broiler chickens of east Azarbayjan by HI tests. Eur. J. Exp. Biol. 3 (6):311-314. 29-Noirot V., M. Champagnac, P. Etienne and D. Eclache 2012. Evaluation of Force 6 Poultry in the diet of heat-stressed broilers.RAA54.R1 page 1-3.

30-Nouzarian, R., S.A. Tabeidian, M. Toghyani, G. Ghalamkari and M. Toghyani. 2011. Effect of turmeric powder on performance, carcass traits, humoral immune responses, and serum metabolites in broiler chickens. Journal of Animal and Feed Sciences. 20 (3):389-400.

31-Olfati, A., A. Mojtahedin, T. Sadeghi, M. Akbari and F. Martínez-Pastor. 2018. Comparison of growth performance and immune responses of broiler chicks reared under heat stress, cold stress and thermoneutral conditions. Spanish Journal of Agricultural Research. 16 (2): 15.

32-Pamoka, S., W. Aengwanich and T. Komutrin. 2009. Adaptation to oxidative stress and impact of chronic oxidative stress on immunity in heat-stressed broilers. Journal of Thermal Biology. 34 (7):353-357.

33-Purwanti, S., Zuprizal, T. Yuwanta and Supadmo. 2014. Duodenum Histomorphology and Performance as Influenced by Dietary Supplementation of Turmeric (Curcuma longa), Garlic (Allium sativum) and its Combinations as a Feed Additive in Broilers. International Journal of Poultry Science. 13 (1):36.

34-Qasem, M.A.A., M.S. Alhaji, A.R. Ger ElNabi and S.I. Al-Mufarrej. 2015. Effect of 
turmeric powder as a dietary supplement on performance indicators and immune response in broiler chickens. Journal of animal and veterinary advances. 14 (2):30-35.

35-Rajput, N., N. Muhammad, R. Yan, X. Zhong and T. Wang. 2013. Effect of Dietary Supplementation of Curcumin on Growth Performance, Intestinal Morphology and Nutrients Utilization of Broiler Chicks. J. Poult. Sci. 50: 44-52.

36-Renaudeau, D., A. Collin, S. Yahav, V. de Basilio, J.L. Gourdine and R.J. Collier. 2012. Adaptation to hot climate and strategies to alleviate heat stress in livestock production. Animal. 6 (5):707-728.

37-Sadeghi, G. H., A. Karimi, S. H. Padidar Jahromi, T. Azizi and A. Daneshmand. 2012. Effects of cinnamon, thyme and turmeric infusions on the performance and immune response in of 1-to 21-day-old male broilers. Brazilian Journal of Poultry Science. 14 (1):15-20.

38-Salami, S. A., M. A. Majoka, S. Saha, A. Garber and J.F. Gabarrou. 2015. Efficacy of dietary antioxidants on broiler oxidative stress, performance and meat quality: science and market. Avian Biology Research. 8 (2):65-78.
39-Santos, R. R., A. Awati, P.J. R. den Hil, M.H.G. Tersteeg-Zijderveld, P.A. Koolmees \& J. Fink-Gremmels. 2015. Quantitative histomorphometric analysis of heat-stressrelated damage in the small intestines of broiler chickens, Avian Pathology, 44:1, 1922. 40-Ürüşan, H. and Ş.C. Bölükbaşı. 2017. Effects of dietary supplementation levels of turmeric powder (curcuma longa) on performance, carcass characteristics and gut microflora in broiler chickens. Journal of animal \& plant sciences. 27 (3):732-736. 41-Viveros, A., S. Chamorro, M. Pizarro, I. Arija, C. Centeno and A. Brenes. 2011. Effects of dietary polyphenol-rich grape products on intestinal microflora and gut morphology in broiler chicks. Poultry Science. 90 (3):566578.

42-Wang, D., H. Huang, L. Zhou, W. Li, H. Zhou, G. Hou, J. Liu and L. Hu. 2015. Effects of dietary supplementation with turmeric rhizome extract on growth performance, carcass characteristics, antioxidant capability, and meat quality of wenchang broiler chickens. Italian Journal of Animal Science. $14(3): 3870$. 